\title{
Teacher's pedagogical competencies on the vocational high school of Padang City
}

\author{
Nellitawati Nellitawati \\ Universitas Negeri Padang
}

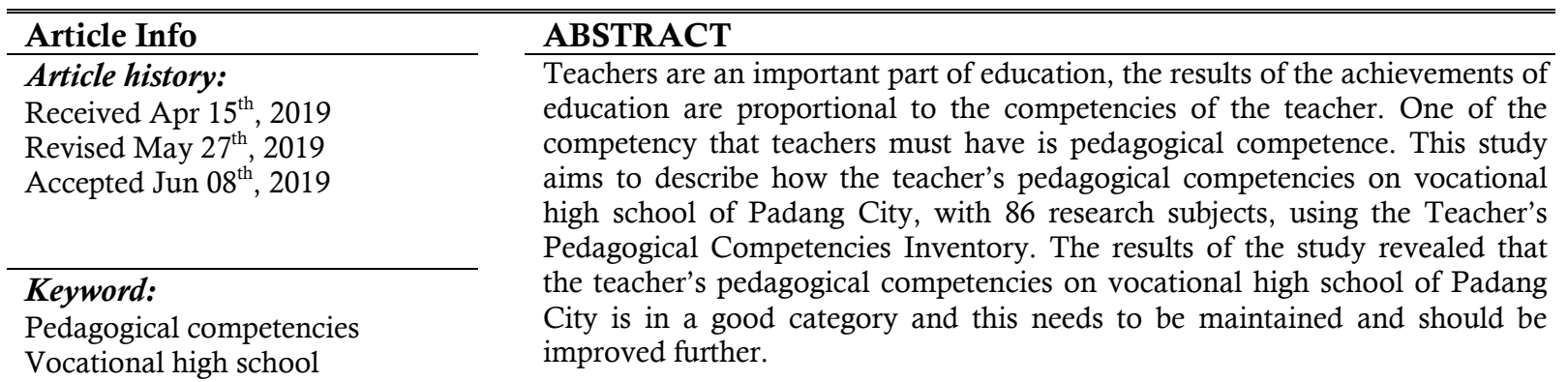

Vocational high school

C 2019 The Authors. Published by Indonesian Institute for Counseling, Education and Therapy (IICET). This is an open access article under the CC BY license (https://creativecommons.org/licenses/by/4.0/)

Corresponding Author:

Nellitawati Nellitawati,

Email: nellitawati@fip.unp.ac.id

\section{Pendahuluan}

Peranan guru sebagai pendidik dan pengajar adalah harus menguasai ilmu, antara lain harus mempunyai pengetahuan yang luas, menguasai bahan pelajaran serta ilmu-ilmu yang berkaian dengan mata pelajaran/bidang studi yang diajarkan, menguasai teori dan praktek mendidik, teori kurikulum dan materi pelajaran, teknologi pendidikan, teori evaluasi dan psikologi belajar (He, Lundgren, \& Pynes, 2017; Kuyini, Yeboah, Das, Alhassan, \& Mangope, 2016). Peran ini disebut kompetensi pedagogik.

Kompetensi pedagogik merupakan kemampuan berkenaan dengan pemahaman terhadap peserta didik dan pengelolaan pembelajaran yang mendidik dan dialogis (Hakim, 2015; Lauermann \& König, 2016; Mirzagitova \& Akhmetov, 2015; Nellitawati \& Boon, 2018). Kompetensi pedagogik adalah sejumlah kemampuan guru yang berkaitan dengan ilmu dan seni mengajar siswa (Abosi \& Alhassan, 2017; Nellitawati \& Boon, 2018; Smith, 2016). Menurut Undang-Undang No. 14 Tahun 2005 tentang Guru dan Dosen kompetensi pedagogik adalah kemampuan mengelola pembelajaran peserta didik (Indonesia, 2005). Pendapat lain menyebutkan kompetensi pedagogik adalah pemahaman terhadap peserta didik, perencanaan, pelaksanaan kegiatan pembelajaran, evaluasi hasil belajar, dan mengembangkan peserta didik untuk mengaktualisasikan berbagai potensi yang dimiliki peserta didik (Andryukhina et al., 2016). Dapat disimpulkan bahwa kompetensi pedagogik adalah kemampuan mengelola pembelajaran yang terdiri dari perencanaan, pelaksanaan kegiatan pembelajaran, evaluasi hasil belajar, dan mengembangkan potensi yang dimiliki siswa sekaligus memfasilitasi pembelajarannya sehingga mencapai tujuan pembelajaran yang diharapkan.

Guru yang memiliki kompetensi pedagogik yaitu guru yang bisa memahami peserta didik, guru yang memahami materi pembelajaran baik teori maupun praktek, menyusun perangkat pembelajaran baik menggunakan media ataupun tidak, mampu mengevaluasi kegiatan pembelajaran, dan juga bisa memberikan motivasi untuk mengembangakan kemampuan peserta didik (Katarzyna, Anna, Paulina, Anna, \& Kinga, 2018; Madhavaram \& Laverie, 2010; Raju, 2017). Sesuai dengan Peraturan Pemerintah Republik Indonesia nomor 19 tahun 2005 pasal 28 ayat (a) tentang standar nasional pendidikan menyebutkan: kompetensi pedagogik adalah kemampuan mengelola pembelajaran yang meiliputi pemahaman terhadap 
peserta didik, perancangan dan pelaksanaan pembelajaran, evaluasi hasil belajar, dan pengembangan peserta didik untuk mengaktualisasikan berbagai potensi yang dimilikinya.

\section{Metode}

Jenis penelitian ini adalah penelitian deskriptif kuantitatif. Penelitian ini menggambarkan kompetensi pedagogik guru di SMK Negeri Kota Padang. Populasi penelitian adalah seluruh guru SMK Negeri Kota Padang yang berjumlah 728 orang, kemudian pengambilan sampel dilakukan secara Stratified Proporsional Random Sampling dan berdasarkan hasil penghitungan, maka didapatkan sampel sebanyak 86 orang guru. Penelitian menggunakan instrumen Teacher's Pedagogical Competencies Inventory. Deskripsi data tersebut dianalisis dengan menggunakan rumus persentase. Data yang sudah dideskripsikan, kemudian dikategorisasikan menggunakan rumus interval.

\section{Hasil dan Pembahasan}

Secara keseluruhan jumlah item pernyataan variabel Kompetensi Pedagogik ada sebanyak 42 butir item, rentang skor 1-5, skor tertinggi adalah 200, dan skor terendah adalah 42. Dengan menggunakan rumus interval, didapatkan kriteria skala kompetensi pedagogik guru secara keseluruhan sebagai berikut.

Tabel 1. Distribusi Frekuensi dan Persentase Kompetensi Pedagogik Guru Berdasarkan Kategori

\begin{tabular}{|c|c|c|c|}
\hline Kategori & Interval Skor & f & $\%$ \\
\hline Sangat Baik & $\geq 176$ & 0 & 0,00 \\
\hline Baik & $142-175$ & 70 & 81,40 \\
\hline Cukup Baik & $108-141$ & 16 & 18,60 \\
\hline Kurang Baik & $74-107$ & 0 & 0,00 \\
\hline Tidak Baik & $\leq 73$ & 0 & 0,00 \\
\hline \multicolumn{2}{|c|}{ Total } & 86 & 100 \\
\hline
\end{tabular}

Berdasarkan Tabel 1, dapat dilihat bahwa sebagian besar kompetensi pedagogik guru pada umumnya berada pada kategori baik yaitu sebesar $81,40 \%$. Hal ini menandakan bahwa guru SMK Negeri Kota Padang memiliki kompetensi pedagogik yang perlu dipertahankan dan sedapatnya di tingkatkan lagi. Kompetensi adalah suatu bentuk tindakan intelegen dengan penuh tanggung jawab yang harus dimiliki seorang dan sikap tanggung jawab yang harus ditunjukan sebagai kebenaran tindakan yang dipandang sebagai kebenaran tindakan ilmu pengetahuan, teknologi dan etika (Instefjord \& Munthe, 2017; Nousiainen, Kangas, Rikala, \& Vesisenaho, 2018). Sementara kompetensi pedagogik adalah pemahaman terhadap peserta didik, perencanaan, pelaksanaan kegiatan pembelajaran, evaluasi hasil belajar, dan mengembangkan peserta didik untuk mengaktualisasikan berbagai potensi yang dimiliki peserta didik. Tentu akan ada fase dimana kompetensi pedagogik ini menjadi menurun karena disebabkan berbagai permasalahan dan kendala yang ada.

Selanjutnya secara rinci deskripsi kompetensi pedagogik guru berdasarkan indikator dapat dilihat pada Tabel 2 berikut.

Tabel 2 Deskripsi Rata-rata (Mean) dan Persentase (\%) Kompetensi Pedagogik Guru Berdasarkan Indikator

\begin{tabular}{|c|c|c|c|c|c|c|c|c|c|}
\hline \multirow[t]{2}{*}{ No } & \multirow[t]{2}{*}{ Indikator } & \multicolumn{8}{|l|}{ Skor } \\
\hline & & Ideal & Max & Min & $\sum$ & Mean & $\%$ & Sd & Ket \\
\hline 1. & $\begin{array}{l}\text { Pemahaman Terhadap } \\
\text { Peserta Didik (7) }\end{array}$ & 35 & 34 & 21 & 2326 & 27,05 & 77,28 & 2,44 & B \\
\hline 2. & $\begin{array}{l}\text { Perancangan dalam } \\
\text { Pelaksanaan } \\
\text { Pembelajaran (7) }\end{array}$ & 35 & 32 & 17 & 2200 & 25,58 & 73,08 & 3,12 & B \\
\hline 3. & $\begin{array}{l}\text { Evaluasi Hasil Belajar } \\
\text { (7) }\end{array}$ & 35 & 32 & 20 & 2125 & 24,71 & 70,6 & 2,78 & B \\
\hline 4. & $\begin{array}{l}\text { Pengembangan Potensi } \\
\text { Peserta didik (21) }\end{array}$ & 105 & 87 & 56 & 6323 & 73,52 & 70,01 & 6,49 & B \\
\hline \multicolumn{2}{|c|}{ Keseluruhan (42) } & 210 & 185 & 114 & 12974 & 150,86 & 71,8 & 14,83 & B \\
\hline
\end{tabular}


Berdasarkan Tabel 2 dapat dilihat secara keseluruhan skor ideal adalah 210, skor tertinggi 185, skor terendah 114 , skor total 12974 , rata-rata skor 150,86 , dan standar deviasi 14,83 . Secara rata-rata capaian terhadap skor ideal adalah 71,8 \%. Berdasarkan tabel tersebut diketahui bahwa secara rata-rata kompetensi pedagogik guru berada pada kategori baik. Hal ini menunjukkan bahwa kompetensi pedagogik guru di SMK Negeri Kota Padang perlu dipertahankan dan sedapatnya ditingkatkan lagi. Berikut penjelasan untuk setiap indikator berdasarkan Tabel 2:

\section{Pemahaman terhadap peserta didik}

Pemahaman terhadap peserta didik pada umumnya berada pada kategori baik, dengan persentase tertinggi dari semua indikator yang ada yaitu 77,28\%. Pemahaman terhadap peserta didik merupakan salah satu kompetensi yang harus dimiliki guru, sedikitnya ada empat hal yang harus dipahami guru dari peserta didiknya, yaitu tingkat kecerdasan, kreatifitas, keadaan fisik, dan perkembangan kognitif (Entwistle \& Ramsden, 2015; Felder \& Brent, 2005; Seifert, 2004).

\section{Perancangan dalam pelaksanaan pembelajaran}

Perancangan pembelajaran mencakup tiga kegiatan, yaitu identifikasi kebutuhan, perumusan kompetensi dasar, dan penyusunan program pembelajaran. Kemampuan guru dalam merancang pembelajaran dikembangkan berdasarkan sub kompetensi yaitu: 1) menerapakan teori belajar dan pembelajaran, 2) menentukan strategi pembelajaran berdasarkan karakteristik peserta didik, 3) menyusun rancangan pembelajaran berdasarkan strategi yang dipilihv(Dalziel, 2003). Berdasarkan hasil penelitian, untuk indikator perancangan dalam pelaksanaan pembelajaran umumnya berada pada kategori baik, dengan persentase 73.08\%. Hal tersebut menunjukkan bahwa guru SMK Negeri Kota Padang memiliki kemampuan yang baik dalam perancangan dalam pelaksanaan pembelajaran.

\section{Evalusi hasil belajar}

Evaluasi hasil belajar pada umumnya berada pada kategori baik, dengan persentase 70,6\%. Evaluasi hasil belajar dilakukan untuk mengetahui perubahan prilaku dan pembentukan kompetensi peserta didik, yang dapat dilakukan dengan penilaian kelas, tes kemampuan dasar, penilaian akhir satuan pendidikan dan sertifikasi, benhmarking serta penilaian program. Dalam mengevaluasi hasil belajar yang perlu diperhatikan adalah sebagai berikut: a) memberikan ukuran yang dipakai, b) mendiskusikan tentang fungsi penilaian untuk memperoleh pemahaman tentang hal-hal apa saja yang dapat dinilai melalui pelaksanaan ujian, c) melaksankan standar penilaian ujian, d) merancang soal-soal ujian dalam struktur soal sedemikian rupa sehingga mengetahui sasaran belajar, e) mengingat derajat kesukaran soal dapat berbeda dengan yang lainnya, f) sesudah di buat soal disajikan melalui ujian, g) pengambilan keputusan atas hasil belajar (Curran, Lockyer, Sargeant, \& Fleet, 2006; Furió, GonzáLez-Gancedo, Juan, Seguí, \& Rando, 2013; Kennedy, 2006). Dapat disimpulkan bahwa bentuk evaluasi hasil belajar yaitu kemampuan guru untuk mengetahui perubahan prilaku dan pembentukan kompetensi peserta didik yang dapat dilakukan dengan penilaian kelas, tes kemampuan dasar, penilaian akhir satuan pendidikan, sertifikasi, serta penilaian program.

\section{Pengembangan potensi peserta didik}

Pengembangan potensi peserta didik dapat dilakukan guru melalui berbagai cara, antara lain dengan melakukan kegiatan ekstrakurikuler, pengayaan dan remedial, serta bimbingan dan konseling. Kemampuan guru dalam pengembangan potensi peserta didik dikembangkan berdasarkan sub kompetensi: a) menfasiliatsi peserta didik untuk mengembangkan berbagai kompetensi akademik yang dikembangkan, b) memfasilitasi peserta didik untuk mengembangkan berbagai potensi non akademik(Schmitt, 2012). Untuk indikator pengembangan potensi peserta didik juga berada pada kategori baik dengan persentase $70.01 \%$.

\section{Kesimpulan}

Berdasarkan hasil penelitian, kompetensi pedagogik guru di sekolah menengah kejuruan Kota Padang berada dalam kategori baik, termasuk empat indikator yang ada, termasuk 1) pemahaman siswa; 2) desain dalam mengimplementasikan pembelajaran; 3) pengujian hasil belajar; 4) potensi pengembangan siswa. Dan ini perlu dipertahankan dan harus ditingkatkan lebih lanjut.

\section{Referensi}

Abosi, O., \& Alhassan, A. R. K. (2017). A Comparative Study of Teachers' Pedagogical Competencies in Supporting Children with Learning Difficulties in Primary Schools in Ghana and Brunei Darussalam. Journal of the American Academy of Special Education Professionals, 62, 76. 
Andryukhina, L. M., Dneprov, S., Sumina, T. G., Zimina, E. Y., Utkina, S. N., \& Mantulenko, V. V. (2016). Vocational Pedagogical Competencies of a Professor in the Secondary Vocational Education System: Approbation of Monitoring Model. International Journal of Environmental and Science Education, 11(14), 7045-7065.

Curran, V., Lockyer, J., Sargeant, J., \& Fleet, L. (2006). Evaluation of learning outcomes in Web-based continuing medical education. Academic Medicine, 81(10), S30-S34.

Dalziel, J. (2003). Implementing learning design: The learning activity management system (LAMS).

Entwistle, N., \& Ramsden, P. (2015). Understanding student learning (routledge revivals): Routledge.

Felder, R. M., \& Brent, R. (2005). Understanding student differences. Journal of engineering education, 94(1), 57-72.

Furió, D., GonzáLez-Gancedo, S., Juan, M.-C., Seguí, I., \& Rando, N. (2013). Evaluation of learning outcomes using an educational iPhone game vs. traditional game. Computers \& Education, 64, 1-23.

Hakim, A. (2015). Contribution of competence teacher (pedagogical, personality, professional competence and social) on the performance of learning. The International Journal Of Engineering And Science (IJES), $4(2), 1-12$.

He, Y., Lundgren, K., \& Pynes, P. (2017). Impact of short-term study abroad program: Inservice teachers' development of intercultural competence and pedagogical beliefs. Teaching and Teacher Education, 66, 147-157.

Indonesia, R. (2005). Undang-undang Republik Indonesia nomor 14 tahun 2005 tentang Guru dan Dosen. Sekretariat Negara. Jakarta.

Instefjord, E. J., \& Munthe, E. (2017). Educating digitally competent teachers: A study of integration of professional digital competence in teacher education. Teaching and Teacher Education, 67, 37-45.

Katarzyna, J., Anna, D., Paulina, K., Anna, M., \& Kinga, S. (2018). Pedagogical Competencies of Teachers at the Beginning of Their Professional Career. Paper presented at the 1 st International Conference on Contemporary Education and Economic Development (CEED 2018).

Kennedy, D. (2006). Writing and using learning outcomes: a practical guide: University College Cork.

Kuyini, A. B., Yeboah, K. A., Das, A. K., Alhassan, A. M., \& Mangope, B. (2016). Ghanaian teachers: competencies perceived as important for inclusive education. International Journal of Inclusive Education, 20(10), 1009-1023.

Lauermann, F., \& König, J. (2016). Teachers' professional competence and wellbeing: Understanding the links between general pedagogical knowledge, self-efficacy and burnout. Learning and Instruction, 45, 919.

Madhavaram, S., \& Laverie, D. A. (2010). Developing pedagogical competence: Issues and implications for marketing education. Journal of Marketing Education, 32(2), 197-213.

Mirzagitova, A. L., \& Akhmetov, L. G. (2015). Self-Development of Pedagogical Competence of Future Teacher. International Education Studies, 8(3), 114-121.

Nellitawati, N., \& Boon, Y. (2018). The role of headmaster to improve pedagogic competence of teachers in Vocational high school.

Nousiainen, T., Kangas, M., Rikala, J., \& Vesisenaho, M. (2018). Teacher competencies in game-based pedagogy. Teaching and Teacher Education, 74, 85-97.

Raju, J. (2017). To teach or not to teach? The question of the academic librarian's pedagogical competencies in the digital age. South African Journal of Higher Education, 31(2), 251-269.

Schmitt, N. (2012). Development of rationale and measures of noncognitive college student potential. Educational Psychologist, 47(1), 18-29.

Seifert, T. (2004). Understanding student motivation. Educational research, 46(2), 137-149.

Smith, J. (2016). Embracing pedagogical competencies for teaching art with culturally diverse students: A'snapshot'from New Zealand. Paper presented at the The Society for Art Education of Korea International Conference. 